\title{
Growth of leopard flower (Belamcanda chinensis) with humics acids in nursery
}

\section{garden}

\author{
Crescimento da flor leopardo (Belamcanda chinensis) com ácidos húmicos em viveiro
}

Crescimento de la flor del leopardo (Belamcanda chinenses) com ácidos húmicos en un vivero

Received: 03/11/2021 | Reviewed: 03/17/2021 | Accept: 03/19/2021 | Published: 03/27/2021

\author{
Libério Junio da Silva \\ ORCID: https://orcid.org/0000-0002-6677-4645 \\ Instituto Brasileiro de Desenvolvimento e Sustentabilidade, Brazil \\ E-mail: liberiojunior25@gmail.com \\ Jorge Rodriguez Lozada \\ ORCID: https://orcid.org/0000-0001-8369-9520 \\ Universidade Federal de Viçosa, Brazil \\ E-mail: jarodriguezlo28@gmail.com \\ Klever Cristiano Silveira \\ ORCID: https://orcid.org/0000-0002-8961-2761 \\ Universidade Federal de Viçosa, Brazil \\ E-mail: klevercris@gmail.com \\ Nilo Leal Sander \\ ORCID: https://orcid.org/0000-0001-9856-6819 \\ Instituto Brasileiro de Desenvolvimento e Sustentabilidade, Brazil \\ E-mail: nilosander@gmail.com \\ Fernanda Figueiredo Granja Dorilêo Leite \\ ORCID: https://orcid.org/0000-0001-9004-6413 \\ Universidade Federal Fluminense, Brazil \\ E-mail: fernandafgdleite@gmail.com \\ Marihus Altoé Baldotto \\ ORCID: https://orcid.org/0000-0002-3239-9082 \\ Universidade Federal de Viçosa, Brazil \\ E-mail: marihus@gmail.com \\ Lilian Estrela Borges Baldotto \\ ORCID: https://orcid.org/0000-0003-1007-1489 \\ Universidade Federal de Viçosa, Brasil \\ E-mail: liestrelaborges@gmail.com
}

\begin{abstract}
Humic acids constitute a fraction of organic matter that either has direct effects on the growth and development of ornamental plants. The present study aimed to evaluate the differential growth of the leopard flower (Belamcanda chinensis) from the application of humic acids extracted from poultry litter $\left(\mathrm{HA}_{\mathrm{PL}}\right)$ and bovine manure $\left(\mathrm{HA}_{\mathrm{BM}}\right)$ during the nursery garden phase. The seeds were immersed in solutions of $0,10,20,30$ and $40 \mathrm{mmol} \mathrm{L}^{-1}$ of $\mathrm{C}$ in $\mathrm{HA}_{\mathrm{PL}}$ and in the same way for $\mathrm{HA}_{\mathrm{BM}}$. After 150 days, the plants were collected and measured the number of leaves, plant height, fresh matter of the aerial part, dry matter of the root, total fresh matter, and dry matter of the aerial part, dry matter of the root and total dry matter. The use of the correct concentration of humic acids stimulates the growth and accumulation of total dry material in the leopard plant in the order of $33 \%$ to $58 \%$ for $\mathrm{HA}_{\mathrm{PL}}$ and $\mathrm{HA}_{\mathrm{BM}}$ respectively.

Keywords: Belamcanda chinensis; Humic substances; Organic matter.
\end{abstract}

\section{Resumo}

Os ácidos húmicos, constituem uma fração da matéria orgânica quer apresenta efeitos diretos no crescimento e desenvolvimento de plantas ornamentais. O presente trabalho teve por objetivo avaliar o crescimento diferencial da flor leopardo (Belamcanda chinensis) a partir da aplicação de ácidos húmicos extraídos de cama de frango (HA $\mathrm{PL}_{\mathrm{PL}} \mathrm{e}$ de esterco bovino $\left(\mathrm{HA}_{\mathrm{BM}}\right)$ durante a fase de viveiro. As sementes foram imersas em soluções de $0,10,20,30$ e 40 mmol L-1 de $\mathrm{C}$ no $\mathrm{HA}_{\mathrm{PL}}$ e da mesma forma para o $\mathrm{HA}_{\mathrm{BM}}$. Após 150 dias as plantas foram coletadas e feitas às medições do número de folhas, altura das plantas, matéria fresca da parte aérea, matéria seca da raiz, matéria fresca total, matéria seca da parte aérea, matéria seca da raiz e matéria seca total. A utilização da concentração correta dos ácidos húmicos estimula o crescimento e o acúmulo de material seco total na planta de leopardo na ordem de $33 \%$ a $58 \%$ para $\mathrm{HA}_{\mathrm{PL}}$ e $\mathrm{HA}_{\mathrm{BM}}$ respectivamente.

Palavras-chave: Belamcanda chinensis; Substâncias húmicas; Matéria orgânica. 


\section{Resumen}

Los ácidos húmicos constituyen una fracción de la materia orgánica que tiene efectos directos sobre el crecimiento y desarrollo de las plantas ornamentales. El presente trabajo tuvo como objetivo evaluar el crecimiento diferencial de la flor de leopardo (Belamcanda chinensis) a partir de la aplicación de ácidos húmicos extraídos de gallinero (HAPL) y estiércol bovino $\left(\mathrm{HA}_{\mathrm{BM}}\right)$ durante la fase de vivero. Las semillas se sumergieron en soluciones de 0, 10, 20, 30 y 40 mmol L-1 de $\mathrm{C}$ en $\mathrm{HA}_{\mathrm{PL}}$ y de la misma forma para $\mathrm{HA}_{\mathrm{BM}}$. A los 150 días se recolectaron las plantas y se tomaron para medir el número de hojas, altura de la planta, materia fresca de la parte aérea, materia seca de la raíz, materia fresca total, materia seca de la parte aérea, materia seca de la raíz y total materia seca. El uso de la concentración correcta de ácidos húmicos estimula el crecimiento y acumulación de materia seca total en la planta de leopardo en el orden de $33 \%$ a $58 \%$ para $\mathrm{HA}_{\mathrm{PL}}$ y $\mathrm{HA}_{\mathrm{BM}}$ respectivamente.

Palabras clave: Belamcanda chinensis; Sustancias húmicas; Materia orgánica.

\section{Introduction}

The world production of flowers occupies approximately 190 thousand hectares and generates an approximate income of 16 billons dollars regarding production and 44 billons when speaking in terms of retail (Benschop et al. 2010; Weber et al. 2017; Mikovski et al. 2019). Thanks to the diversity of species possessing Brazil, many native and introduced flowers have a high potential for economic exploitation (Ibraflor, 2012), one of these is known as the common name flower leopard (Belamcanda chinensis). Plant Family “Iridaceae", herbaceous, perennial, floriferous and native to China and Japan, height 50$90 \mathrm{~cm}$, flattened, long and arranged on the fan-shaped stem flowers, its inflorescence is erect, branched, with yellow-orange flowers with yellow dots (Lorenzi, 2008; Szandruk et al. 2018; Song et al. 2018; Téllez et al. 2020).

The ornamental plants international merchandise is widely competitive and seasonal pointed by periods of high demand and others of relative calm (Asocolflores, 2005). The production and marketing of flowers concentrated in two big actors Netherlands and Colombia, each one with $58.2 \%$ and $13.4 \%$ severally, of the world market (Fao, 2004). Other countries that have a strong presence are Italy, Denmark, France, Ecuador, and Mexico (Fao, 2004). The productivity of ornamental leopard flower is primarily evaluated by the plat height and commercial quality of inflorescences (Yang et al. 2012; Ji et al. 2020; Santos-Silva et al. 2020). Thus, different factors influence these variables such as climatic and soil conditions, mineral nutrition, irrigation quality, and the use of plant growth regulators (Maciel et al. 2013; Silva et al. 2013; Li et al. 2018).

In this context, the root-cutting treatment with humic substances that directly influence the growth and development of ornamental plants, which can be an alternative to increase the production and quality of the leopard ornamental plant (Baldotto et al. 2012, 2013, 2015).

The humic acids represent a short part of the organic material corresponding to the fraction of the humic soluble substance in alkaline ways. The HA application can accelerate the germination and improve the height qualities, leaf area, weight of the dry material (root and shoot) and hence oleraceous and floriculture species production (Arancon et al., 2003; Primo et al., 2011; Baldotto et al., 2014). Although at the market there are commercial products that have the same work of the HA that is to give macro and micronutrients for the plant, increasing rooting and vegetative development (Bezerra et al., 2007), with high costs that do not allow small producers to access these products.

The present work has as an objective evaluate the growth of a floral species with commercial potential Leopard flower (Belamcanda chinensis), as an answer to the application of five concentration of HA obtained from poultry litter and five concentration of HA obtained from bovine manure under nursery control conditions.

\section{Methodology}

The experiment was conducted in the nursery garden of Departament of Floriculture of the Federal of Viçosa University

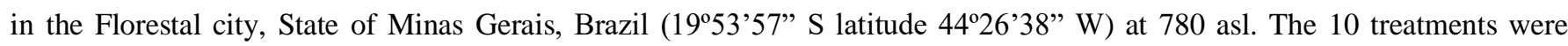
distributed in the following order (Table 1). 
Table1. Treatments used in the test.

\begin{tabular}{|c|c|c|}
\hline Treatment & Origin of Humic Acid & Concentration \\
\hline 1 & Poultry Litter & $0 \mathrm{mmol} \mathrm{L}{ }^{-1} \mathrm{C}$ \\
\hline 2 & Poultry Litter & $10 \mathrm{mmol} \mathrm{L}^{-1} \mathrm{C}$ \\
\hline 3 & Poultry Litter & $20 \mathrm{mmol} \mathrm{L}^{-1} \mathrm{C}$ \\
\hline 4 & Poutry Litter & $30 \mathrm{mmol} \mathrm{L}^{-1} \mathrm{C}$ \\
\hline 5 & Poultry Litter & $40 \mathrm{mmol} \mathrm{L}^{-1} \mathrm{C}$ \\
\hline 6 & Bovine Manure & $0 \mathrm{mmol} \mathrm{L}^{-1} \mathrm{C}$ \\
\hline 7 & Bovine Manure & $10 \mathrm{mmol} \mathrm{L}^{-1} \mathrm{C}$ \\
\hline 8 & Bovine Manure & $20 \mathrm{mmol} \mathrm{L}^{-1} \mathrm{C}$ \\
\hline 9 & Bovine Manure & $30 \mathrm{mmol} \mathrm{L}^{-1} \mathrm{C}$ \\
\hline 10 & Bovine Manure & $40 \mathrm{mmol} \mathrm{L}^{-1} \mathrm{C}$ \\
\hline
\end{tabular}

Source: Authors.

The HA was previously isolated and evaluated by Baldotto et al. (2014). The leopard flower seeds (Belamcanda chinensis) were immersed in the solutions of the treatment for 24 hours. Previously they were seeded in $130 \mathrm{~cm}^{3}$ tube containing soil, chemically characterized by having $\mathrm{pH}=4.84 ; \mathrm{P} 34 \mathrm{mg} \mathrm{dm}{ }^{-3} ; \mathrm{K}=486.5 \mathrm{mg} \mathrm{dm}^{-3} ; \mathrm{Ca}^{2+}=3.63 ; \mathrm{Mg}^{2+}=3.73$; $\mathrm{Al}^{3+}=0.29 ; \mathrm{Al}+\mathrm{H}=7 ; \mathrm{Sb}=8.56 ; \mathrm{CEC}=8.86$ (all previous values are $\mathrm{cmol}_{\mathrm{c}} / \mathrm{dm}^{-3}$ ).

The experimental unit consisted of two plants per tube, which remained in the nursery garden covered by $50 \%$ shade. The design used was completely randomized with ten treatments and 15 replications for each treatment, five different concentrations of HA of two different types: humic acid extracted from poultry litter and bovine manure.

The analyzed variables were: the number of leaves (LN) by plant for each of the repetition, the height of the plant from it base until it apex with a measuring tape; also the measure of fresh matter shoot (FMS), fresh matter root (FMR) and fresh matter total (FMT) using the scale Shimadzu AY 200; subsequently, the samples were placed to dry in a forced air oven at $60^{\circ}$ for 7 days and measurements of dry matter shoot (DMS), dry matter root (DMR) and the fresh matter total (FMT) were performed.

\section{Results and Discussion}

The results of the analysis of growth and production of ornamental plants of leopard (Belamcanda chinensis) in response to the increased concentration of the application of humic acids (HAPL and HABM) showed a difference in the performance of rooting and development of the aerial part, as shown in the table below (Table 2). The studied variables were positively influenced by the treatment of leopard flower with humic acids. 
Table 2. Medium, residual mean square (RMS) and coefficients of variation (CV\%) for the number of leaves (NL), plant height (PH), fresh matter of shoots (FMS), fresh matter of root (FMR), fresh matter total (FMT), dry matter of shoot (DMS), dry matter of root (DMR) and total dry matter (DMT) as a function of increasing concentrations $\left(0,10,20,30,40 \mathrm{mmol} \mathrm{L}^{-1}\right.$ of C) isolated humic acid poultry litter ( $\left.\mathrm{HA}_{\mathrm{PL}}\right)$ and bovine manure $\left(\mathrm{HA}_{\mathrm{BM}}\right)$.

\begin{tabular}{lcccccccc}
\hline Treatment & NL & HP & FMS & FMR & FMT & DMS & DMR & DMT \\
\hline & & - -cm-- & - -g-- & - -g-- & - -g-- & - -g-- & --g-- & --g-- \\
\cline { 2 - 8 } $\mathrm{HA}_{\mathrm{PL}}(0)$ & 3 & 14 & 0.5304 & 0.1707 & 0.7012 & 0.0906 & 0.0781 & 0.1687 \\
$\mathrm{HA}_{\mathrm{PL}}(10)$ & 3 & 15 & 0.6270 & 0.3391 & 0.9662 & 0.1043 & 0.1069 & 0.2112 \\
$\mathrm{HA}_{\mathrm{PL}}(20)$ & 3 & 16 & 0.6215 & 0.2257 & 0.8472 & 0.1175 & 0.0907 & 0.2083 \\
$\mathrm{HA}_{\mathrm{PL}}(30)$ & 4 & 16 & 0.6609 & 0.2184 & 0.8793 & 0.1206 & 0.1123 & 0.2329 \\
$\mathrm{HA}_{\mathrm{PL}}(40)$ & 3 & 15 & 0.6027 & 0.1516 & 0.7544 & 0.1026 & 0.1092 & 0.2118 \\
$\mathrm{HA}_{\mathrm{BM}}(0)$ & 3 & 14 & 0.5304 & 0.1707 & 0.7012 & 0.0906 & 0.0781 & 0.1687 \\
$\mathrm{HA}_{\mathrm{BM}}(10)$ & 3 & 16 & 0.6471 & 0.2708 & 0.9179 & 0.1171 & 0.1016 & 0.2187 \\
$\mathrm{HA}_{\mathrm{BM}}(20)$ & 3 & 16 & 0.6269 & 0.3359 & 0.9628 & 0.1112 & 0.1200 & 0.2313 \\
$\mathrm{HA}_{\mathrm{BM}}(30)$ & 4 & 16 & 0.6591 & 0.3669 & 1.0266 & 0.1127 & 0.1119 & 0.2247 \\
$\mathrm{HM}_{\mathrm{BM}}(40)$ & 3 & 15 & 0.5831 & 0.2555 & 0.8386 & 0.0955 & 0.0845 & 0.1800 \\
$R M S$ & 0.2711 & 29.894 & 0.0286 & 0.0176 & 0.06944 & 0.000861 & 0.00279 & 0.00488 \\
$C V(\%)$ & 15.3 & 11.2 & 27.8 & 53 & 30 & 27.6 & 53.3 & 34 \\
\hline
\end{tabular}

Source: Authors.

The curves regarding the response of the application of increasing concentrations of humic acids from bovine manure and poultry litter showed quadratic variation (Table 3). Due to the size of these equations, the concentrations of maximum physical efficiency DMT of the leopard plant were calculated for the concentration of $\mathrm{HA}_{\mathrm{PL}}$ and $\mathrm{HA}_{\mathrm{BM}}$. 
Table 3. Regression equations for the characteristics, number of leaves (NL), plant height (PH), fresh matter of shoots (FMS), fresh matter of root (FMR), fresh matter total (FMT), dry matter of shoot (DMS), dry matter of root (DMR) and total dry matter (DMT) as a function of increasing concentrations $\left(0,10,20,30,40 \mathrm{mmol} \mathrm{L}^{-1}\right.$ of C) isolated humic acid poultry litter $\left(\mathrm{HA}_{\mathrm{PL}}\right)$ and bovine manure $(\mathrm{HA} \mathrm{BM})$.

\begin{tabular}{|c|c|c|c|}
\hline Variable & $\mathrm{AH}$ & Equation & $\mathrm{R}^{2}$ \\
\hline \multirow[t]{2}{*}{ NL } & HAPL & $\hat{y}=3,431-0,0259 x+0,0021 x^{2}-0,00004 x^{3}$ & 0,9821 \\
\hline & $\mathrm{HA}_{\mathrm{BM}}$ & $\hat{y}=3,404+0,0137 x-0,0005 x^{2}$ & 0,6388 \\
\hline \multirow[t]{2}{*}{ HP } & $\mathrm{HA}_{\mathrm{PL}}$ & $\hat{y}=14,064+0,186 x-0,0042 x^{2}$ & 0,9055 \\
\hline & $\mathrm{HA}_{\mathrm{BM}}$ & $\hat{y}=14,306+0,2032 x-0,0045 x^{2}$ & 0,9466 \\
\hline \multirow[t]{2}{*}{ FMS } & $\mathrm{HA}_{\mathrm{PL}}$ & $\hat{y}=0,535+0,0093 x-0,0002 x^{2}$ & 0,8719 \\
\hline & $\mathrm{HA}_{\mathrm{BM}}$ & $\hat{y}=0,5383+0,0107 x-0,0002 x^{2}$ & 0,8354 \\
\hline \multirow[t]{2}{*}{ FMR } & $\mathrm{HA}_{\mathrm{PL}}$ & $\hat{y}=0,2009+0,0088 x-0,0003 x^{2}$ & 0,5629 \\
\hline & $\mathrm{HA}_{\mathrm{BM}}$ & $\hat{y}=0,1615+0,0157 x-0,0003 x^{2}$ & 0,9432 \\
\hline \multirow[t]{2}{*}{ FMT } & $\mathrm{HA}_{\mathrm{PL}}$ & $\hat{y}=0,7359+0,0182 x-0,0004 x^{2}$ & 0,6490 \\
\hline & $\mathrm{HA}_{\mathrm{BM}}$ & $\hat{y}=0,6998+0,0264 x-0,0006 x^{2}$ & 0,9423 \\
\hline \multirow[t]{2}{*}{ DMS } & $\mathrm{HA}_{\mathrm{PL}}$ & $\hat{y}=0,0886+0,0025 x-0,00005 x^{2}$ & 0,9285 \\
\hline & $\mathrm{HA}_{\mathrm{BM}}$ & $\hat{y}=0,0929+0,0023 x-0,00006 x^{2}$ & 0,8506 \\
\hline \multirow[t]{2}{*}{ DMR } & $\mathrm{HA}_{\mathrm{PL}}$ & $\hat{y}=0,0822+0,0014 x-0,00002 x^{2}$ & 0,5978 \\
\hline & $\mathrm{HA}_{\mathrm{BM}}$ & $\hat{y}=0,0763+0,0039 x-0,00009 x^{2}$ & 0,9748 \\
\hline \multirow[t]{2}{*}{ DMT } & $\mathrm{HAPL}_{\mathrm{PL}}$ & $\hat{y}=0,1707+0,0039 x-0,00007 x^{2}$ & 0,8607 \\
\hline & $\mathrm{HA}_{\mathrm{BM}}$ & $\hat{y}=0,1692+0,0062 x-0,0001 x^{2}$ & 0,9938 \\
\hline
\end{tabular}

Source: Authors.

The maximum efficient values of DMT were observed for the HAPL to a concentration of $28 \mathrm{mmol} \mathrm{L}^{-1}$ of $\mathrm{C}$ and weight of 0.2250 grams and for the $\mathrm{HA}_{\mathrm{BM}}$ the maximum efficient value was found in a concentration of $31 \mathrm{mmol} \mathrm{L}^{-1}$ of $\mathrm{C}$ and a reach weight of $0.2653 \mathrm{~g}$. We can infer that with the use of the correct concentration we can obtain DMT increases of 33\% concerning the control. When compared the data with maximum efficiency between HAPL and HA $\mathrm{BM}_{\mathrm{BM}}$ can be observed that there are no different means between the HA. The decision of which HA will be used will depend on the availability of the material for the producer.

The results corroborate studies of Baldotto et al. (2009) where they observed increases in growth and development of in vitro plantlets of pineapples in response to the application HA. Baldotto et al. (2014) in a test of acclimatization of orchid (Cymbidium sp.) in response to application humic acid, also observed increments in the development and growth of seedlings after application of humic acid. Bernardes et al. (2013), to study the effect of the application of humic substance in tomato seedlings, concluded that HA is accelerator metabolisms of plants favoring a high development and therefore significant increases the DMT. Similar results were also found by Arancon et al. (2003), in the study effects of vermicomposts to tomatoes 
and peppers grown in the field and strawberries under high plastic tunnels. The use of an adequate concentration of HA encourages rooting and plant development.

\section{Conclusion}

The treatment of ornamental leopard flower cuttings with humic acids increases the number and quality of the flower stems and the concentration range of both evaluated humic acids that induce maximum efficiency in the production and quality of ornamental leopard stems was 5-10 mmol L-1 and $15-30 \mathrm{mmol} \mathrm{L}^{-1}$ for poutry litter and bovine manure respectively. This shows that the application of HA in appropriate concentrations for each species, stimulates the production of seedlings, favoring the of oleraceous and flowers sectors.

Thus, the use of humic substances in promoting plant growth is of fundamental importance, since this practice reduces the use of chemical fertilizers that lead to serious environmental problems. Therefore, the development of research aimed at accelerating the production of ornamental plants with the use of organic compounds should be increasingly encouraged to grant improvements in the distribution system of these goods, guaranteeing an expansion of the consumer culture without major associations with the environment.

\section{Acknowledgments}

The Fundação de Amparo à Pesquisa do Estado de Minas Gerais (FAPEMIG); National Council for Scientific and Technological Development (CNPq); Fundação Arthur Bernardes (Funarbe), for the financial support for this research. The public servants Floriculture Sector UFV-CAF.

\section{References}

Arancon, N. Q., Edwards, C. A., Bierman, P., \& Metzger, J. D. (2003). Effects of vermicomposts to tomatoes and peppers grown in the field and strawberries under high plastic tunnels. Pedobiologia, 47(6), 731-735.

Asocolflores. (2005). Casos Susteniblidad. <https:/www.cecodes.org.co/descargas>.

Baldotto, L. E., Baldotto, M. A., Bazoni, V. G., Canellas, L. P., Olivares, F., \& Bressan-Smith, R. (2009). Desempenho do abacaxizeiro 'Vitória' em resposta à aplicação de ácidos húmicos durante a aclimatação. Revista Brasileira de Ciência do Solo, 33(4), 979-990.

Baldotto, L. E., Baldotto, M. A., Brandão, J., Miranda, F., \& Gonçalves. J. (2014). Aclimatização de orquídea (Cymbidium sp.) em resposta à aplicação de ácidos húmicos. Ciência Rural, Santa Maria, 44(5), 830-833.

Benschop, M., Kamenetsky, R., Le Nard, M., Okubo, H., \& De Hertogh, A. (2010). 1 The Global Flower Bulb Industry: Production, Utilization, Research. Horticultural Reviews, 36(1), 1-115.

Bernardes, J. M., Reis, J. M. R., \& Rodrigues, J. F. (2011). Efeito da aplicação de substância húmica em mudas de tomateiro. Global Science and Technology, 4(3), 92-99.

Bezerra, P. S. G., Grangeio, L. C., Negreriros, M. Z., \& Mederiros, J. F. (2007). Utilização de bioestimulante na produção de mudas de alface. Científica, Jaboticabal, 35(1), 46-50.

dos Santos-Silva, D. L., da Silva, G. S., da Silva Gomes, G., Oliveira, R. F., da Costa Gaspar, J., Araujo, M. D. F. V., \& da Conceição, G. M. (2020). Potencial ornamental de samambaias e licófitas no Leste do Maranhão, Brasil. Research, Society and Development, 9(7), e278974087-e278974087.

FAO. (2004). FAO Trade Policy Technical Notes on issues related to the WTO negotiations on Agriculture. <www.fao.org $>$.

Freitas, F. R. (1995). Grande crescimento no mercado das flores. Agroanalysis, 15(9), 8-11.

Guerra, J. C., Santos, G. A., Silva, L. S., \& Camargo, F. A. (2008). Macromoléculas e substâncias húmicas. In: Santos, G.A. Ed. Fundamentos da matéria orgânica do solo: ecossistemas tropicais \& subtropicais. (2a ed.), Metrópole, p.19-26.

Ibraflor. (2014). Diretoria de Atas. <www.ibraflor.com/diretoria_atas.php>.

Ji, Y., Fang, Q., Liu, S., Zhang, B., \& Long, C. (2020). Herbal Medicinal Markets in China: An Ethnobotanical Survey. In Medicinal Plants: Biodiversity, Sustainable Utilization and Conservation, 415-429. 
Research, Society and Development, v. 10, n. 3, e56310313792, 2021

(CC BY 4.0) | ISSN 2525-3409 | DOI: http://dx.doi.org/10.33448/rsd-v10i3.13792

Li, S., Tian, Y., Wu, K., Ye, Y., Yu, J., Zhang, J., \& Fu, X. (2018). Modulating plant growth-metabolism coordination for sustainable agriculture. Nature, 560(7720), 595-600.

Lorenzi, H., \& Moreira H. (2008). Plantas ornamentais no Brasil: arbustivas, herbáceas e trepadeiras. (4a ed.), CIP 2008. 683.

MAPA. Câmaras Setoriais- AGES- FLORES. Ministério da Agricultura, Produção e Abastecimento. <www.agricultura.gov.br>.

Primo, D. C., Menezes, R. C., \& Silva, T. O. (2011). Substâncias húmicas da matéria orgânica do solo: uma revisão de técnicas analíticas e estudos no nordeste brasileiro. Scientia Plena, 7(5).

Song, Y. Y., Miao, J. H., Qin, F. Y., Yan, Y. M., Yang, J., Qin, D. P., \& Cheng, Y. X. (2018). Belamchinanes A-D from Belamcanda chinensis: Triterpenoids with an Unprecedented Carbon Skeleton and Their Activity against Age-Related Renal Fibrosis. Organic letters, 20(17), 5506-5509.

Szandruk, M., Merwid-Ląd, A., \& Szeląg, A. (2018). The impact of mangiferin from Belamcanda chinensis on experimental colitis in rats. Inflammopharmacology, 26(2), 571-581.

Téllez, H. O., do Bomfim, G. V., de Carvalho, A. C. P. P., de Azevedo, B. M., \& Lozano, C. H. G. (2020). Paclobutrazol no desenvolvimento de mudas de plantas matrizes de abacaxizeiro ornamental. Research, Society and Development, 9(10), e2349108478-e2349108478.

Yang, C., Liu, X., \& Wei, Y. (2012). Quality Evaluation of Belamcanda Chinensis in Fujian. Journal of Fujian University of Traditional Chinese Medicine, 03 .

Weber, O. B., Crisostomo, L. A., Miranda, F. R. D., Sousa, A. F., Mesquita, A. L. M., \& Cabral, J. E. D. O. (2017). Production of ornamental sunflower irrigated with oilfield produced water in the Brazilian semiarid region. Pesquisa Agropecuária Brasileira, 52(6), 443-454. 